\title{
EFFECTS OF DELAYED TREATMENT, ARTHRALGIA, AND ANEMIA, ON THE CURE AND SURVIVAL IN PATIENTS WITH MULTI DRUG-RESISTANT TUBERCULOSIS
}

\author{
Linda Soebroto, Reviono, Yusup Subagio Sutanto \\ Department of Pulmonology and Respiratory Medicine, \\ Faculty of Medicine, Universitas Sebelas Maret, Surakarta
}

\begin{abstract}
Background: Multidrug-resistant tuberculosis had high treatment failure and mortality. Success rate of treatment currently $56 \%$ at global level and $48 \%$ in Indonesia. This study aimed to determine the effects of delayed treatment, arthralgia, and anemia, on the cure and survival in patients with multi drug-resistant tuberculosis.

Subjects and Method: This was a retrospective cohort study conducted at Dr. Moewardi Hospital, Surakarta, Central Java, from January 2015 to August 2020. A sample of 372 drug resistant tuberculosis patients who underwent treatment were selected for the study. The dependent variables were treatment failure (inverse of cure) and mortality (inverse of survival). The independent variables were delayed treatment, arthralgia, and anemia. The drug resistant tuberculosis patient data were obtained from the medical record. The data were analyzed using Cox proportional hazard model.

Results: Delayed treatment $(\mathrm{HR}=2.91 ; 95 \% \mathrm{CI}=1.89$ to $4.47 ; \mathrm{p}=<0.001)$ and arthralgia $(\mathrm{HR}=1.77,95 \% \mathrm{CI}=1.15$ to $2.74 ; \mathrm{p}=0.010)$ were associated with an increased chance of treatment failure. Delayed treatment $(\mathrm{HR}=14.77 ; 95 \% \mathrm{CI}=13.38$ to $16.16 ; \mathrm{p}<0.001)$, arthralgia $(\mathrm{HR}=15.17 ; 95 \% \mathrm{CI}=13.96$ to $16.39 ; \mathrm{p}<0.001)$, and anemia $(\mathrm{HR}=15.30 ; 95 \%$ $\mathrm{CI}=14.07$ to $16.53 ; \mathrm{p}=0.002$ ) were associated with an increased chance of mortality.

Conclusion: Delayed treatment, arthralgia, and anemia are associated with increased chance of treatment failure and mortality.

Keywords: delayed treatment, arthralgia, anemia, treatment failure, mortality, drugresistant tuberculosis

\section{Correspondence:}

Linda Soebroto. Department of Pulmonology and Respiratory Medicine, Faculty of Medicine, Universitas Sebelas Maret. Jl. Ir. Sutami 36A, Surakarta 57126, Central Java. Email: soebrotolinda@hotmail.com. Mobile: 081332335559.
\end{abstract}

